\title{
THE EUROPEAN UNION AND THE CHALLENGE OF ENLARGEMENT
}

\author{
Sevilay KAHRAMAN*
}

\begin{abstract}
The objective of the article is to assess the impact of enlargement on the evolution of the relationship between deepening and widening of the Community. The article deals with the enlargements of the 1970s and 1980s, the 1995 enlargement and the probable Eastern enlargement of the EU and how they affect the process of deepening of the Community. Having presented the evidence that widening has so far been accompanied by modest deepening via limited institutional reform which resulted in the eventual extension of the powers of the EC's institutions, it concludes by arguing that the future enlargements of the EU will succeed only if widening is reconciled with deepening in a Community model of differentiated integration.
\end{abstract}

\section{Introduction}

Wider or deeper? That is the question now being posed about the future of European Union (EU)'. It is an old question which has preceded the establishment of the EU. It may well be argued that it was the question which originally split Western Europe into two groupings; namely the inner Six of the European Community (EC) and the outer Seven of the European Free Trade Association (EFTA) in the late1950 s.

Each time the member governments were confronted with the demands of the non-EC countries for joining, they have had to ask themselves whether further enlargement would advance or retard the momentum towards EU. In particular, the re-

- Dr., Department of International Relations, Middle East Technical University

1 Throughout this article, the notion "European Community" (EC) is meant to encompass both the European Economic Community (EEC), based on the Rome Treaty, and the European Political Cooperation (EPC) regarding foreign policy cooperation between the Twelve. The term "European Union" (EU) adds the two pillars of Common Foreign and Security Policy (CFSP) and Cooperation in the Fields of Justice and Home Affairs (CJHA) to the EEC (renamed simply the EC) and refers to the union established by the Maastricht Treaty. 
lationship of widening in the sense of admitting new members to deepening of the scope and level of integration remains central to the debate ${ }^{2}$. In other words, the basic problem regarding the probable expansion of the EU to 20-plus members is its implications for the EU's policy competence and institutional structure.

After three successive waves of enlargement, to include Britain, Denmark, Ireland in 1973, Greece, Spain and Portugal throughout the 1980s and finally Austria, Sweden and Finland in 1995, the EU is once again on the way for further expansion to include some of the countries of Central and Eastern Europe (CCEE) which have signed Europe agreements with the EU (the Czech Republic, Slovenia, Poland and Hungary) and the Mediterranean states which have signed association agreements with the EU (Cyprus, Malta?, Turkey?) $)^{3}$. The Intergovernmental Conference (IGC) which began its work in March 1996 is intended to address the policy and institutional reforms needed to prepare the EU for the further rounds of enlargement over the next decade.

Although enlargement has been a consistent Community objective, the issue has not received much scholarly attention. While several empirical studies have examined the implications of enlargement for the applicant states, less attention has been paid to the effects of enlargement on the development of European integration". The fact that integration theory is not so enlightening on this issue enable us to suggest that practical and historical experience of the EC is of greater relevance. ACcordingly, a glance back at the transition of the EU from the Six, to the Nine, to the Twelve and to the Fifteen seems to be more useful to understand the contemporary enlargement debate.

2 Paul Taylor (1983: 106) has distinguished between the scope and level of integration: scope refers to the horizontal effecl of integration, the number of functional areas which were linked logether in some way within the larger territory, level refers to the manner in which the areas were organized-in particular-the extent to which they were ruled from new centres which could act independently from governments.

3 The simultaneous accession of the UK, Denmark and Ireland constituted the northem enlargement of the Community, and although Greek membership of the EC preceded those of Spain and Portugal, the three can reasonably be combined as a single process of southern enlargement.

The Norwegian government also negotiated accession terms wice in 1972 and 1994 but were rejected in a referendum. However, the fact that Swedish and Finnish membership meant that eighty per cent of the Nordic population would be within the EU makes another Norwegian application probable.

German re-unification brought about a widening of the EC in that the unification made the territory of the former German Democratic Republic not only part of Germany but also part of the Community. However, as Nugent (1992: 316) has noted this was a unique sort of widening, not least because it did not involve the usual mechanics of joining the Communily.

4 Nonetheless, there are a tew exceptions, one of them being the study by Michalski and Wallace (1992). For an account of the implications of enlargement for theorizing on European integration, see Miles et. al (1995). 
The aim of this study is to evaluate the earlier processes of enlargement of the EU, and on the basis of the lessons derived from the history of the EU's enlargement, to identify the main issues associated with the current enlargement debate. As we shall see while the context of widening of the 1990s and the characteristics of the candidates are unique, there are still lessons that can be drawn from the past enlargements.

\section{From the Six to Twelve}

Article 237 of the Treaty of Rome stipulates that any European state may apply to become a member of the Community. Undoubtedly, the founding fathers' call for "the other peoples of Europe who shared their ideal to join in their efforts" in the Preamble to the Treaty, was directed towards the northern outsiders, particularly to Britain, than to the southern neighbours. However, the British dislike of supranationalism as the organizing principle of the European Coal and Steel Community (ECSC) and its long-run federal aspirations restricted the membership of the Community to the six continental countries. As Pinder (1991: 45) has noted the success of the ECSC demonstrated that the continentals could go ahead without Britain. Although the defeat of the European Defence Community (EDC) was a setback to the advance of European integration along federal lines, the ECSC countries were able to relaunch economic integration in a more comprehensive manner, which was to be built around the idea of a common market. The failure of the British attempts to unite West European countries under a broader European free trade area within the Organization for European Economic Cooperation (OEEC) led to the formation of the European Economic Community (EEC) in 1957. As a response, Britain, together with Denmark, Sweden, Norway, Austria, Switzerland and Portugal set up the EFTA in 1960. The postwar economic division of Western Europe was then consolidated.

After the failure of the EC to complete, deepen and widen in the 1960 s due to de Gaulle's resistance to both, the integration strategy of the early 1970 s was once again to pursue all three goals simultaneously. The Hague Summit of December 1969 was a turning point in the history of the EC since it indicated the willingness of the Six to relaunch European integration on the eve of enlargement. The revival of European integration took the form of a new package deal which was described by President Pompidou in terms of a triptych consisting of completion, deepening and enlargement. Completion, the principal French interest in the Community, involved the establishment of a system of "own resources" with which to finance the Common Agricultural Policy (CAP). Deepening included the movement towards Economic and Monetary Union (EMU) and the creation of an intergovernmental system of foreign policy coordination, which became known as the European Political Cooperation 
(EPC), a high priority on the West German agenda. Finally, the first enlargement negotiations with Britain, Denmark, Ireland and Norway were successfully concluded in January 1972, and all but Norway became full members of the EC on 1 January 1973. Thus "deepening and widening as justifiable and viable simultaneous processes entered into EC thinking and history, if not reality" (Laurent, 1994: 27).

However, the combination of increasing economic and political diversity in the EC with a period of international economic turbulence made it clear that the search for deepening and widening simultaneously would prove to be extremely difficult. In fact, enlargement took precedence and the first EMU project was lost in the oil crisis, the subsequent economic recession and Europessimism of the 1970s.

From the perspective of the Community, there had been clear integration costs as a result of the first enlargement (Wallace, 1989: 2). While Ireland proved easy to absorb, Britain and Denmark had difficulties with the practical consequences of the acquis communautaire and showed continuing resistance to Community deepening ${ }^{5}$. The hope of some optimists that "the new members would boost the democratization of the EC through the EP's quest for direct elections and power", soon turned out to be idle (Lodge, 1989: 60). None of the new members was as pro-integrative as the new Iberian entrants. Britain and Denmark, together after 1981, with Greece, resisted proposals they felt would erode national sovereignty, including Euro-elections which meant "a zero-sum loss of sovereignty for the national parliaments" (Lodge, 1989: 61).

Furthermore, during the reform process of 1985-86 which led to the signing of the SEA, the three member states adopted a minimalist approach to institutional reform, reasserting the right to veto when "very important national interests" were at stake and accepting only an informal extension of majority voting. Nor did the minority of the Three give consent to the idea of convening an IGC to negotiate a draft EU Treaty "which looked suspiciously like the constituent assembly of a federal union" (Taylor, 1989: 9). Nonetheless, the Three did eventually participate in the work of the IGC with an expectation that the outcome in practical terms would be much less farreaching than the rhetoric (George: 1990: 183) ${ }^{6}$. Indeed, the agreements that were eventually reached at the Luxembourg Summit of December 1985 and were in-

5 According to Holland, "the vague consensus on objectives and an immature Communily spirit in the 1970 s were largely responsible for the ensuing difficulies the Community experienced, particularty with the UK and Denmark" (Holland, 1993: 166-67). He further added that "by the 1980s, however, the existing acquis communautaire was more definitively expressed, and the issue of integration and evolution of the Community was not an issue that Greece, Portugal or Spain could properly ignore" (Holland, 1993: 166).

6 For a detailed account of the SEA negotiations, see Moravcsik (1991). 
corporated into a final document titled as the SEA was considered to be an achievement for the minimalists ${ }^{7}$.

Obviously, the institutional stalemate of the Community from the mid-1960s to the mid-1980s cannot be wholly attributed to enlargement. Nevertheless, the intergovernmentalist tendencies of some of the late-comers played a major role in imposing limits to the institutional development of the Community along federal lines. Indeed, the first wave of enlargement meant that the prospect of further political integration via institutional reform would not be so easy".

By contrast, the enlargement to the south had no such restraining effects on the institutional deepening of the EC, rather it helped the member governments to undertake major steps for reforming the Community policies and institutions through the Single European Act in 1986.

One characteristics that distinguishes Southern enlargement from its predecessor was the political commitment of the aspirant states to the Community membership. As mentioned earlier, the degree of national commitment to the EC has been rather low from the northern newcomers. While the British and Danes tended to underemphasize the political content of the process of European integration so that the national debates on joining the EC had concentrated on the economic aspects of membership, in Spain and Portugal, there was little debate on the political implications of EC membership. Rather, EC membership was seen as a means of reinforcing the return to democracy, as a means of promoting political and economic reform and liberalisation and as the redefinition of national identities and orientations which has been associated with a broader process of "Europeanisation" (Rosenthal, 1982: 4).

By contrast, Greek attitudes to the EC have long been characterized by degrees of division and ambivalence. While Greece's ties with Western states and organisations hava long enjoyed strong support from the conservative New Democracy

7 As Moravcsik has argued "the SEA negotiations can be interpreted as a process of limiting the scope and intensity of reform-a process necessary to gain the acceptance not only of Britain but also of other member states who, when it came to drafting a document, suddenly proved quite jealous of their sovereignty. ... The maximalist programme of broad reform was progressively sacrificed in favour of the minimalist programme limited to those procedural and substantive changes needed to liberalize the internal marker" (Moravcsik, 1991: 61).

While the overall impact of 1973 enlargement on the institutional development of the Community was hardly supportive, its impact on policy development was more positive. The expansion of the EC from the original Six to Nine contributed to the development of fisheries, regional and environmental policies and the EPC. Partly inspired by the need to provide a package of trade preferences and aid for the Commonwealth countries in Africa, the Caribbean and the Pacific (ACP), the first Lome Convention was signed in 1975 between the EC and 46 ACP states. 
Party (founded by Karamanlis after 1974), Papandreou's PASOK (the Pan-Hellenic Socialist Party) essentially represented the anti-Western section in Greece's political culture.

Greece's EC policy during the period of the Papandreou government consisted mainly of securing as much economic support from Brussels as possible. For PASOK, any advance towards EU must be linked with convergence of the member states' economies and that in order to maintain this linkage it was essential to retain unanimous voting in the Council (Verney, 1987: 226-267). Not surprisingly, Greece joined the minimalist group for resisting the supranational institutional development of the Community in the 1980 s.

While the post-accession experience of Greece with the EC proved to be more troublesome than was expected, the results of the first decade of Spanish and Portuguese Community membership have been more positive. For the Iwo Iberian countries, "EC membership not only accelerated economic growth and structural change, but also brought welfare gains to most of their inhabitants and progressive changes in attitudes, institutions and practices" (Bideleux, 1996: 149).

While the PASOK government gradually softened its reluctant attitude towards economic integration, its foreign policy of national independence in the early 1980 s proved to be an obstacle for Greece to adopt the EC's acquis politique. Greece, together with Denmark explicitly rejected the idea of consolidation and strengthening of EPC. Instead, it required EPC "to retain its intergovernmental character and stressed the importance of reaching common positions by consensus in an attempt to safeguard the Greek sovereign right to define its own foreign policy" (den Hartog, 1992: 90). Although, the pro-EC New Democracy Party seemed to adopt a more positive approach to the debate on EPU in 1990-91, the change in the Greek attitude towards European political integration was short-lived, however. PASOK's innate nationalism which was re-elected in October 1993, resurfaced in two major forms: first, the Greek sympathy and support for the Serbs during the Yugoslavian crisis; second, Greek opposition against Western recognition and support for the newly independent Republic

9 By the time Greece became a full member in January 1981, conditions within and outside the Community had become more difficult. The second oil crisis of 1979-80 had severely depressed the European economy and Greek membership was proving difficult to digest. The fact that Greece took Portugal's place as the poorest member of the Community prevented her to reap the full benefits of the SEM and possibly the EMU. As Bideleux (1996: 135) has marked, by the end of 1993, Greece was in the last place on all four of the "convergence criteria" for participation in EMU as laid down at Maastricht. 
of Macedonia and Albania. Hence, in admitting Greece, the EU imported conflicts with Turkey and more recently with the fragile post-Communist Balkan states ${ }^{10}$.

In contrast to Greece which was known as the "enfant terrible" of EPC in the early 1980s, Spain and Portugal have contributed to foreign policy cooperation among the Twelve. As one commentator on EPC has concluded, "the more member states that the EC/EPC took in, the wider was the panopoly of views to be harmonised-a problem in the case of Greece since 1981-and the richer the diplomatic connections became-an asset in the case of Spain and Portugal since 1986" (Rummel, 1994: 118).

It may, therefore, be concluded that there existed marked differences between the two phases of enlargement on the grounds of economic and political compatibility of the applicants for Community membership and the overall impact of enlargement on the scope and level of European integration. While the accession of the three northern states and Greece into the EC coincided with a period of stagnation in the history of the Community, the late 1980s was the time of resurgence of the Community when the member states assembled another reform package that included agreement on completion, deepening and widening. As Wallace has remarked: "the 1992 goal was clearly intended as completion, but new policies had been substantively embraced and institutions had been strengthened, thus deepening was in hand, and widening had $0 \mathrm{c}$ curred for a third time without momentum being lost" (Wallace, 1989: 6).

One fundamental issue for the EC, as it has been enlarged to the South, was how to reconcile desires for further integration, that is completion and deepening with the facts of enlargement and diversity, or how to avoid the risk of "widening and dilution".

10 On the Community side, Greek membership gave an end to the pursuit of an even balance in relations with Greece and Turkey. Contrary to the earlier statement of the Greek government that "it was nol going to use its future position in the EC's decision-making bodies to impede the strengthening of ties with Turkey" (quoted in Siotis, 1983: 68), the Greeks have used their advantageous position inside the EC to gain acceptance over bilateral dispules with Turkey. Besides continous efforts to gain the support of its European pariners, Greece has used its veto power to impede the improvement of Turkey-EC relations. That Greece was able to do so was also because, the Turco-Greek dispute could act as a shelter for the rest of EU members which firmly believed that Turkish entry at a time when the Community itself has been in a state of profound transition would not be to the advantage of the EC.

In recent years, Turkish accession is closely linked to a settlement of the dispute over Cyprus. In particular, the withdrawal of Turkish troops form northern Cyprus may well be the minimum price that Turkey has to pay before it can join the EU. This marked the beginning of a shift in the approach of the EC which, has, after Greek entry, refrained from playing an active role as a moderator in the Cyprus dispule (Tsoukalis, 1981: 134). Nonetheless, the fact that Greece is a full member but Turkey only an associate member makes the EU unsuitable as a mediator (Redmond, 1993: 77). Hence, in assessing the triangular relationship between Greece, Turkey and the EU, the question of whether or not the analogy with Franco-German reconciliation is a meaningful one remains to be seen. 


\section{The Single European Act: The Reform Package of Completion, Deepening and Widening}

As the Mediterranean enlargement emerged on the Community agenda, some academicians and practitioners who were concerned about the risks of dilution began to look for a more flexible and pragmatic approach to the future course of the EC. Thus, by the early 1980s, integration strategies and enlargement became interwoven in the renewed debate about the Community's future development. As the discussion was under way, a number of new concepts entered the discourse of the EC debate, all falling under the general rubric of "differentiated integration": Europe à la carte, variable geometry, two speed/ two-tier Europe, graduated integration and concentric circles".

Underlying the proposed models for the EC was an understanding that the original model of uniform and unilinear process of integration was no longer appropriate for the Community (Wallace, 1983: 431). All the proposed strategies for managing diversity had in common the idea of a new and flexible form of integration in which not all member states would be involved in every Community action at the same time and in the same form (Langeheine and Weinstock, 1985: 186).

Indeed, the flexible approach to integration is not a new idea. It has been developing for a long time both in law and in fact. However, the prospective southern enlargement of the EC gave rise to a renewed discussion of a differentiated integration. One notable work was the Tindemans report of 1976 which made reference to the notion of a two-speed Europe in the field of EMU as a response to the challenge of enlargement. Implied was an understanding that there was no antithesis between widening and deepening, rather an idea that "new accessions should not slow down the development of the Union nor jeopardize it" (Tindemans, 1976: 34). Although the idea was never formally adopted, the European Monetary System (EMS) which was set-up in 1978-79 recognized that not all member states would necessarily fully participate from the onset. In addition to the EMS, variable geometry was illustrated by the European Research Coordination Agency (EUREKA), Schengen agreements, WEU and EUROCORPS.

11 These strategies for managing diversity are discussed in Wallace (1985). See also Wallace (1983) and Langeheine and Weinstock (1985). 
The debate about differentiated Europe resurfaced again before and during the SEA negotiations to wield against the recalcitrant states, notably Britain ${ }^{12}$. Of the Twelve, only the British interpreted the SEA as mainly about completion and widening. The EMU and the Social Charter have become the key issues on both of which there was strong opposition from the British government ${ }^{13}$. The concessions granted to the UK in the Maastricht negotiations and to Denmark afterwards re-opened the debate, and as we shall see later, the challenge of enlargement of the Union eastward has further aggravated it.

Against the advocates of pragmatism, the further extension of deepening via policy and institutional reform has been a consistent priority amongst European integrationists. The agenda for a comprehensive reform of the Community had been set by the EP with its adoption of the Draft Treaty on EU in (EUT) February $1984^{14}$. That the member governments were to become convinced of the need to act on institutional matters owed something to the persistent pressure from the EP and to their own concerns that the EC's further enlargement would produce institutional and policy deadlock.

While the EUT was the major catalyst for action on the institutional front, the Cormmision's White Paper, a legislative blueprint for completing the EC's internal market by the end of 1992 was the major catalyst on the policy front ${ }^{15}$. Doubtless, the

12 In his address to the EP in May 1984, Mitterrand expressed his suppont for a new treaty of EU and spoke of the possibility of a "two-speed" Europe, if not all the members wished to move quickly along this route. The idea of a new trealy "opened up the prospect of a more supranational inner core, which the UK could only join at the expense of its sovereignty" (Taylor: 1989: 7 ). Thus as Taylor put it (1989: 6) the strategy of implying support for higher levets of integration from which the UK could be excluded, occurred to Mitterrand as a way of dealing with the British budgetary problem. It was in such a Community context, and as a result of the skillful patterns of diplomacy between France, Germany and Britain that the EC governments were to resolve the long-standing disputes over major issues, including the UK budgetary rebale, and were able to proceed on the road towards an IGC on substantive and policy reform.

13 While the Thatcher government saw the 1992 programme as no more than the freeing of the European market, the Delors Commission linked monetary union, the social dimension and further institulional reform to the programme. In her Bruges speech of Oclober 1988, Thatcher fiercely criticized the extended concept of 1992 as envisaged by the Commission. Eventually, though it was Thatcher's strong line against the idea of monetary union that led to her resignation. Funthermore, her strong Allanticism which caused her to oppose the need for a clearer European defence identity was another controversial issue between Thatcher and her cabinet.

The removal of Thatcher from the leadership in November 1990 made it much easier to reach a consensus on both monetary union and political union (George, 1992: 62). The Major govemment's eventual acceptance of the idea of a European security and defence identily-including the role of the WEU as a bridge between NATO and EU-enabled it to play a more active role in the debate over the CFSP. The fact that the Allanticist approach prevailed in that field, at least for the time being, was one of Britain's desires.

14 For a detailed analysis of the EP's Draft Treaty for European Union, see Bieber et al (1985) and Lodge (ed.) (1986).

15 See Commission (1985). The White Paper is extensively analysed in Bieber et al (1998). 
Delors Commission which took office in January 1985 has been at the heart of the major changes associated with the 1992 programme ${ }^{16}$. The Commission did not only successfully fulfil its role as an agenda-setter, but also bear responsibility for the transition of the internal market programme into a broader package of the SEA.

Though the SEA was driven by the EP's project, the EC governments rejected the EUT's neofederal option for using the EC as the basis of a new constitution for a EU (Lodge, 1990: 217). Instead they favoured the minimalist approach of amending the Treaties of Rome. However, SEA's minimalism combined with its pragmatism and incrementalism turned out to be the main reason for its eventual acceptance by the Twelve. More importantly, the SEA essentially sought to resolve two incompatible goals; the expansion of the EC's policy competence, and improving the EC decisionmaking process so that competences can be used more effectively and democratically.

I shall not provide a detailed examination of the SEA since it has already been analysed in depth elsewhere ${ }^{17}$. Instead I make an overview of its content. Though the internal market programme constituted the core of the Act, it is worth stressing that the SEA is about both market and governance: central to realising many SEA goals, especially the internal market, was the idea of relorming the EC's decision-making process. The successiul implementation of the 1992 programme was, to a large extent, an outcome of the two interrelated procedural reforms which the SEA brought about; the extension of qualified majority voting (MV) in the Council to measures necessary for the establishment and functioning of the internal market, and the introduction of a new cooperation procedure which provides for a second reading through which the EP has been given increased influence, if not a power of co-decision, in the legislative process ${ }^{18}$. A real power of co-decision has been conferred on the EP only with regard to the conclusion of accession treaties and association agreements, where the Council may act in the future only with Parliament's assent.

In addition to reforms that the SEA introduced into the EC decision-making, it expanded the scope of EC's competence into six new policy areas, although most of them already existed in practice in one form or another. The first relates specifically to the completion of the internal market, the rest respectively to cooperation in economic and monetary policy (EMU), social policy, economic and social cohesion, research and technological development and the environment.

16 See Ludlow (1992: 116-21).

17 See Commission (1986). For an analysis of the origins and consequences of the SEA for Community deepening, see Cameron (1992) and Kahraman (1996: 161-178).

18 See Lodge (1987). 
Both monetary integration and foreign policy cooperation have long been viewed by European federalists as potentially path-breaking routes to EU. However, these two important policy areas have been carefully delimited in the SEA, albeit they are now firmly treaty-based: there was no merger of political cooperation and the Community arena, nor was there any decision of freeing the EMS from the procedure of Article 236 EEC which requires national ratification in each of the member states for any further institutional reform deemed necessary by progress in that field.

The SEA did not only produce pressures for a deepening of economic integration but also represented a significant step in the institutional transformation of the EC in the mid-1980s s. $^{19}$ The agreement to convene the two IGCs on EMU and EPU within a few years after the adoption of the SEA symbolizes the ever-widening scope of the EC's policy agenda, as does the re-assertion of confidence over the Community and its institutions. Launched as an act of adaptation to the new imperatives of economic and technological change, the SEA can be said to have constituted an example of "system transformation" which implies going beyond the original treaty commitments and taking on new commitments either geographically or functionally ${ }^{20}$.

The SEA reform package, coupled with the 1988 structural reforms allowed spillover from the internal market programme into the Community's latest initiatives for EMU and EPU. In addition to generating pressures for internal spillover, the SEA and the 1992 programme might be considered as "an example of external spillover whereby the benefits of integration are seen to invite outside participation of the elites of aspiring EC members" (Miles et al, 1995: 182).

19 The adoplion of the 1992 programme and the SEA did not only conslitule an important step for remedying the institutional shortcomings of the Community, but also opened up a new pluralistic debate on integration theory. The stagnation of European integration in the 1970 s led many EC observers to conclude that integration theories had become obsolele. By contrast, the post-SEA period has witnessed an increasing academic attention to the origins, meaning and consequences of the remarkable transformation in the EC. On the one hand, we see a reappraisal of neofunctionalism and is notion of spillover, as theorists have used to explain the sudden dynamism of the Community. On the other hand, in response to the renaissance of neofunctionalism, there has also been a revival of intergovernmentalism-a Community version of Realpolitik. More important perhaps is a third group of studies which have sought a balance between the two approaches, often including insights from the domestic politics approach. For the post-neofunctionalist explanation of European inlegration process since the mid-1980s, see Tranholm-Mikkelsen (1991) and Corbey (1995). For a neo-intergovemmentalist analysis, see Moravcsik $(1991,1994)$ and for the third group of studies, see Hoffmann and Keohane (1991) and Cameron (1992). 


\section{The Deepening and Widening of the European Community in the 1990s}

The SEA and the internal market have had profound external implications for the EC ${ }^{21}$. Indeed, if any further evidence of the potential significance of 1992 is needed, it could be found in the reaction of those West European states which have stayed outside the EC. As the Community moved toward and even beyond the objective of 1992, the non-EC states have found their own ability to act independently of the EC's decisions and practices became more and more limited.

Thus further enlargement beyond the Twelve has been on the agenda of the EC since Turkey's application for full membership of the EC in April 1987. Although the Turkish application coincided with the entry into force of the SEA, it was not so much an outgrowth of the dynamic developments in the Community, but an outcome of the domestic political and economic considerations of the time. By contrast, the Austrian application in June 1989 which was followed by those of Sweden, Finland, Switzerland and Norway respectively was based on a conviction that the European Economic Agreement (EEA) offered no real influence on EC decision-making and that only EC membership could give them full acess to rights and obligations of the Community. Thus the political and institutional limitations of the EEA agreements was one of the reasons for their applying. This was given even greater urgency following the dramatic changes in Eastern Europe in 1989-90 which raised the possibility of an eastward enlargement in the longer term. For the EFTA states, the willingness to differentiate their own aspirations from those of the East European countries provided an additional stimulant to entry ${ }^{22}$.

When the two founding members of EFTA, the UK and Denmark joined the EC in 1973, free-trade agreements were signed between the EC and remaining EFTA members with the aim of creating a European space for industrial products. Athough this had not fully materialized, there has been a high degree of mutual dependence between the two groupings. The need to maintain trade relationships after the creation of single market was of particular significance for the EFTA states and this even-

21 For a discussion of the external dimensions of the move towards a single European market, see Redmond (ed.) (1992).

22 As Edwards has stated "following the signing of the Europe agreements, in terms of industrial Irade, the CCEE would be on a par with the EFTA countries within an economic area. ... The way in which these agreements could include a political and even a security dimension raises a further difficulty for the EFTA states, of whom only Norway in the past has been interested in a political dialogue" (Edwards, 1991: 35). 
tually led to steps towards closer cooperation culminating in the creation of the EEA (previously known as European Economic Space) in May $1992^{23}$.

In the late 1980s, when the Cold War still dominated East-West relations in Europe, full membership of the EC was not considered a serious option for the neutral EFTA countries (Austria, Sweden, Finland). Nor were the Commission and the majority of EC members advocating any further enlargement before the end of 1992. Indeed, until 1991, the formal position of the EC was that completion of the internal market and further deepening of integration towards EMU should take priority over enlargement. Accordingly, in his speech to the EP in January 1989, President Delors suggested an alternative formula for the EFTA group, which he referred as "a more structured partnership with common decision-making and administrative institutions". The EFTA countries welcomed this initiative and the negotiations for an EEA opened in June 1990. There was, therefore, a tacit agreement between the two sides that EC-EFTA cooperation should aim at partial (economic) membership, instead of full membership, the possibility of full membership would be deferred, but not ruled out (Pedersen, 1993: 34).

Delors' offer for an EEA was to be an integral part of his broader notion of a Europe of concentric circles: by strengthening institutional arrangements with EFTA partners, Delors wanted to make EFTA a genuine pillar within Europe's future economic architecture ${ }^{24}$. However, the idea of Europe of concentric circles and the EC's strategy of consolidation and partnership that underlined it, lost much of its initial attraction due to pressures of change both in the Community and in Europe. In the early 1990s, the European political architecture began to shift away from an image of concentric circles to one where the European system was increasingly becoming the EC itself, to enlarge sooner or later. This compelled the EC and the Commission, in particular, to abandon its former strategy of "deepening before widening" and to search strategies for reconciling both.

23 The EEA had been agreed in October 1991, but formal signing and implementation was delayed when the European Court ruled in December 1991 that the joint EU.EEA arbitration mechanisms were incompatible with the Treaties of Rome. Following its signing in May 1992, the agreement eventually came into force in January 1994.

By the end of 1992, however, five EFTA countries, namely Austria, Sweden, Switzerland, Finland any Norway had applied for membership of the EC. But in December 1992, the Swiss turned down the EEA agreement in a referendum. So the possibility of Switzerland joining the Community now looks rather improbable. For a historical overview of EC-EFTA relationship, see Pedersen (1994).

24 The EEA agreement would be first tightest circle around the EC. The next are the association agreements, including the older ones with the Mediterranean countries and the newer ones with the CCEE. Beyond the association circle, there will be countries having trade and cooperation agreements such as the Baltic states and the members of the Commonwealth of Independent States. 
By the time the EEA agreement had been negotiated, the EC had itself moved ahead; the two IGCs started in December 1990 and concluded with the adoption of the TEU by the European Council of Maastricht in December 1991. The provisions of the Treaty are set out in more detail elsewhere $e^{25}$. Suffice it here, therefore, to give a brief overview of the most important advances with regard to institutional and policy deepening of the EC.

\section{The Implications of the Maastricht Treaty for Community Deepening and Widning}

It has been argued that (Laursen, 1993: 127) the Maastricht Treaty continues the logic of the SEA, but it goes further than the SEA, both in form and content. The Treaty not only committed the member states to establishing EMU by 1999, but it was also an important step on the road towards EPU. Regarding policy deepening, The Treaty does not only strengthen some policy areas which were first given recognition via the SEA, but also extends EC competences to new areas such as education, culture, public health, consumer protection, and industrial policy. Moreover, these new policy areas will largely be subject to QMV. Unanimity is basically retained, however, for certain social policy matters, for budgetary matters, for the review of structural funds, for treaty amendments and for the CFSP.

While extending the EC's scope of policy competences, the Union Treaty, at the same time, introduces the principle of subsidiarity which sets limits to Community activity by providing that "any action by the Community shall not go beyond what is necessary to achieve the objectives of the Treaty" and that the Community will act "only if and in so far as the objectives of the proposed action cannot be sufficiently achieved by the member states" (Article $3 \mathrm{~b}$ EC) ${ }^{26}$.

Perhaps the most promising achievement of Maastricht lies in the gradual transformation of the EPC into a CFSP. The new CFSP seems to be a major improvement of the EPC. It is to cover all areas of foreign and security policy, including the eventual framing of a common defence policy, which might in time lead to a common defence. The WEU is declared to be an integral part of the development of the Union and has the function of implementing the decisions of the latter which have defence implications. Although the CFSP is not fully integrated into the EC pillar, in some respects, it aims at the communitarization of relations within the scope of the

25 For an account of the IGC on EPU, see Laursen and Vanhoonacker (eds) (1992). For an in-depth analysis of the Maastricht Treaty, see Corbett (1993) and Duff et al (1994).

26 For an extensive discussion of the principle of subsidiarity, see Wike and Wallace (1990) and Van Kersbergen and Verbeek (1994). 
CFSP. One innovation, for instance, is the introduction of QMV in the area of CFSP, although heavily restricted to procedural questions and only applicable in cases of joint action.

Furthermore, in line with the logic and demands of the single market the new Treaty included cooperation in the fields of justice and home affairs as the third pillar of the emerging Union.

In addition to broadening EC's policy competences, Maastricht introduces changes into the institutions and legal system of the Community. In view of the limitations of the SEA from the perspective of democratic legitimacy, the member states sought to address the problem of democratic deficit by enhancing the EP's role in the legislative process ${ }^{27}$. To this end, the Treaty extended the scope of the assent procedure and that of the cooperation procedure. More importantly, Article 189b EC introduces a new, albeit limited co-decision procedure ${ }^{28}$.

The EC has also been suffering from an implementation deficit which became more apparent in the post-SEA period. Prompted by the divergences among the EC countries concerning their capacity to implement and enforce EC law, the enforcement procedure under Articles 169-171 EEC were amended. It is now provided that a

27 One of the persistent aims of the institutional reform of the EC was to increase the democratic legitimacy of the Community legislative process. However, the SEA, far from redressing democratic deficit, has accentuated it: while it enhanced the elficiency of Community decision-making, the extension of OMV exacerbales democratic deficil by weakening parliamentary control of the Council, as ministers could no longer be accountable to their governments for those measures which they might have voted against and disapprove of. The post-SEA Community, therefore, saw a weakening of the national parliamentary control of the Council. Moreover, this decline on the part of national partiaments has not been compensated with any subtantial increase in the powers of the EP, even under the new TEU.

While some EC states like Germany, Italy and the Benelux countries explicilly linked their final consent to EMU to the strengthening of the legislative powers of the EP, others including the UK, Denmark and France opposed to an enhancement of EP's powers. Altematively, they argued that democracy in the Community could be better achieved by securing the greater involvement of national parliaments. Two Declarations were then added to the TEU, one encouraging greater involvement of national parliaments in the activities of the EU, the other inviting the EP and national parliaments to meet as a conference of parliaments or "assises".

As the ratification of the Maastricht Trealy became a difficult process, the EC govemments began to divert attention from changes to the inter-institutional balance to greater openness and transparency of the Commission.

28 Under co-decision, a conciliation cornmittee is foreseen when under the system of two-readings, the Council does not approve the text as amended. If the Council fails to reach an agreement with the EP in conciliation, it will be able to adopt it. The text would become law unless the EP rejected it by an absolute majority within six weeks. It is by virtue of this feature that the new procedure constitutes a genuine power of co-decision, although some observers prefer the term negative assent.

The scope of the new procedure is limited, however, the most important ones are Article 100ainternal market harmonization and Article 100b-internal markel mutual recognitions, but there is provision in Article 189b EC for its application to be extended on the basis of a report to be submitted to the Council by the Commission by 1996. 
financial penalty may be imposed on member states which fail to comply with the judgments of the ECJ within the time-limit laid down by the Commission.

As far as the future development of European integration is concerned, one striking feature of the TEU is the way it makes special provision for particular members-most notably the UK. Regarding EMU, this takes two forms: the mechanism of exclusion and opting-out (Hartley, 1993: 232-34). Those member states that do not qualify under the convergence criteria are referred to as "member staies with a derogation" and they will not participate in decision-making on the management of the European currency. These arrangements could be viewed as the beginning of a multi-speed Europe, as in making progress with EMU, the Treaty raises the possibility for the split of Community into a core of single-currency states and an outside group of "member states with a derogation".

Also, Protocol No. 11 and No. 12 provide the UK and Denmark with the possibility of permanently opting-out of the third stage of EMU which correspond to the notion of "à la carte" integration. An immediate opting-out is provided for the British under Protocol No. 14 on Social Policy because of the refusal by the UK to envisage any extension of social policy planned for the future Union. Finally, at the Edinburgh Summit of December 1992, Denmark was given opt-outs from the third stage of EMU and from the defence dimension of the CFSP.

Thus, by opening the route for a more flexible EC increasingly characterized by institutional pluralism and perhaps also by different memberships in different policy spheres, Maastricht facilitated widening in a less direct way (Nugent, 1992: 321).

\section{From the Twelve to Fifteen}

In making progress with policy and institutional deepening, the Maastricht Summit paved the way for widening. At Britain's insistence, the EU leaders welcomed enlargement without naming the candidate countries. Enlargement negotiations on the basis of the new Treaty could start as soon as the Community had terminated its negotiations on the budget package and related issues in 1992. The EC leaders also invited the Commission to examine the implications of enlargement for the EU's future development. Beyond this, little or no attempt was made to take account of the impact of future enlargement on the internal development of the Community. This was largely because the attitudes of the EC countries to deepening and widening diverged in priorities and in the preferred nature and pace of change ${ }^{29}$.

29 For a detailed analysis of different national views on widening or deepening of the EC, see Michalski and Wailace (1992: 53-9). 
Germany and the UK supported further enlargement of the EU, albeit for different reasons. The Germans considered the enlargement from Twelve to Fifteen to be a prerequisite for the entry of the CCEE, a high priority on the German agenda. The debate about EFTA enlargement was part of a larger argument over whether insitutional changes should be made before the accessions or at the 1996 Conference. While Germany strongly advocated the latter, the French and Italians, had initially given priority to deepening (especially on EMU and CFSP matters) than widening, in order to prevent a possible dilution of the EU. Although France was aware that it had little to gain from northern enlargement, the possibility that the new members might establish close links with Germany which might, in turn, weaken its partnership with Germany prompted a change in the French stance. In autumn 1992, France together with Germany supported enlargement negotiations with the EFTA group ${ }^{30}$.

Unlike the other larger member states which tended to combine Community deepening with widening, Britain has expressed a marked preference to a policy of "widening without deepening" since the time of southern enlargement. There has been a persistent concern inside the Community that Britain's support for EFTA enlargement and beyond was motivated by its minimalist position on deepening: it saw widening that would bring in more states which were suspicious of federal and centralizing tendencies as a major opportunity to put brake on further moves toward deepening.

The Benelux countries were favourable to enlargement but shared a concern that further enlargement might undermine the position of the smaller members within the EC ${ }^{31}$. Finally, for Greece, Spain, Portugal and Ireland, the link between enlargement and the completion of the budget negotiations as a means for ensuring their economic and social cohesion was of special importance.

As a result, the intergovernmental debate sought in large part to ensure that further Community deepening was guaranteed before widening issues were tackled: in particular, this has taken the form of preventing Euro-sceptics-notably the UK-from using the pressures for widening as an excuse for slowing down the deepening process (Nugent, 1992: 319-20).

30 Having failed to secure support for its proposal for a European confederation which would help to lengthen the CCEE's stay outside the EC, the French government stressed during the IGCs, first, the guarantee of parallelism between German unification and European integration, and second, the necessity of deepening of the Community rather than its hurther expansion. France's eventual acceptance of EFTA enlargement was contingent upon the candidates' accepling the provisions of the TEU and those of the CFSP in particular. However, the French position on enlargement has not softened to the point of agreeing to allow the CCEE to become EU members in the near future.

31 See the Benelux Memorandum (1992). 
However, the uncertainty over the future of the Union Treaty due mainly to ratification and referendum crises forced EC countries to authorize the opening of membership negotiations early in 1993, before the full ratification of the Treaty. Accordingly, the enlargement negotiations were officially opened with Austria, Sweden and Finland on 1 February 1993 and with Norway, which applied later, on $5 \mathrm{April}^{32}$. The negotiations were the least problematic in that the EFTAns were prosperous, were stable democracies, and were closely linked to the EC through the EEA experience. On the other hand, the fact that these negotiations were the first to concern accession to the EU made it clear that the new applicants have had to fully accept the acquis communautaire, including the objectives of the TEU, notably the EU acquis on EMU and on CJHA, and the acquis politique or the CFSP as defined in the new Treaty.

Indeed, the swift and smooth progress of the enlargement negotiations led the Community to seek a more concerted attempt than had been previously to develop a strategy for conducting its relations with non-EU countries. The June 1993 Copenhagen Summit shed the green light for an Eastern enlargement agreeing that "accession will take place as soon as an associated country is able to assume the obligations of membership by satisfying the economic and political conditions required" (European Council, 1993: 5). The fulfilment of these criteria requires adjustment on the part of the candidate countries and by the EU in that the latter must be able "to absorb new members, while maintaining the momentum of European integration" (European Council, 1993: 5).

Before examining the problems and prospects of enlarging the EU beyond 15 , we shall look more closely into the overall implications of EFTA enlargement for the existing Union.

Originally, the EEA looked more like a half-way house to the EFTA countries, offering participation in the EC's internal market but not requiring involvement in a number of cooperation areas such as the EPC. When the formal EEA negotiations opened in June 1990, most EFTAns still thought their neutrality to be incompatible with the finalites politiques (or ultimate political goals) of the Community. However, following the break-up of the Soviet Union, neutrality has no longer come to be seen by those states as an obstacle to full membership, even though the EC countries were now calling for the transformation of the EPC into a CFSP, including the prospect of an eventual common defence policy.

The Commission was, however, more cautious on this issue. In its report on enlargement submitted to the Lisbon Summit, it stressed the need for compliance with the EU's acquis, including the TEU and its political objectives as the basic condition for new members. Furthermore, the applicants should also be able to accept and 
implement the CFSP. In this area, the report stressed that "specific and binding assurances will be sought from the applicant countries with regard to their political commitment and legal capacity to fulfil their obligations (Commission, 1992: 13).

Institutional questions in connection with enlargement was another particular concern of the Commission. The Lisbon report (Commission, 1992: 14-5) stressed the need for the effective functioning of an enlarged Union and suggested that a more rigorous application of the principle of subsidiarity as well as further reforms to reduce the "democratic deficit" and to strengthen the role of the EP would be necessary. Thus, prior to the first Danish referendum, the Commission considered further institutional reforms necessary for preparing the EC for future enlargements. However, in the wake of the referendum, it seemed to adopt the view that EFTA enlargement might take place without institutional changes beyond those of size. The European Council of Lisbon shared the Commission's view that 'this enlargement is possible on the basis of the institutional provisions contained in the TEU and attached declarations" (European Council, 1992: 23). Thus, unlike previous enlargements, the Community's expansion to include Austria, Sweden and Finland on 1 January 1995 was not accompanied by far-reaching institutional changes, rather the issue was left to the next IGC, with the new members taking part.

From the economic point of view, EFTA enlargement would not undermine the Community by the increasing diversity, since the newcomers do share similar economic experiences and levels with the existing EC members. Already, the EEA agreement turned these countries into "silent" participants in the EC's single market. As Cameron (1995: 33-4) has noted the speed of the 1993-94 negotiations demonstrated the high degree of preparedness on the part of the applicant states due to the considerable degree of harmonization occurred within the EEA framework.

Also, being net contributors to future EC budgets, the EFTAns could share the EC burden, particularly in transfers of resources to poorer members and outsiders. As Laurent (1994: 133) has marked EFTA enlargement would make the EC a more solid anchor in material terms for the Community's further expansion to the East. Yet, this did not prevent the possibility for another distributional conflict within the EC, since the southern members were concerned about the shift of balance northward and a corresponding weakening of the Mediterranean front in the Community.

The greatest difficulty that might arise is, rather, in the attitudes of new members to the process of deepening. The new members' initial preference for the EFTA to the EC was a reflection of their long-standing antipathy to "an ever closer union" and their reluctance to surrender sovereignty to central institutions, especially outside the economic area. All Three have, therefore, remained suspicious of the concept of a federal Europe. The lack of support for federalism in these countries is not restricted to elite level but is also apparent within parties and public opinion. Hence, it seems likely that the 1995 newcomers will join the group of minimalists, and a larger 
coalition of minimalists within an enlarged EU, will surely increase the likelihood of differentiated integration for the future.

Furthermore, the accession of the EFTA states which have a tradition of using referenda could have faltering implications for further deepening of European integration. In the post-accession period, public opinion will continue to be a crucial variable in determining the Austrian, Swedish and Finnish EU policy. More specifically, the public attachment to neutrality as an expresson of national identity in these states will be an important factor in determining the new member governments' attitude towards the development of the CFSP.

The Maastricht ratification crisis has already revealed a much expanded gap between governments and the electorate, despite the introduction of the principle of European citizenship at Maastricht. The first major incident on the road to a smooth ratification process was the Danish rejection of the TEU in June $1992^{33}$. The Danish vote, stimulated a wider public debate on European integration process as citizens in other EC countries began to have a more critical look at the implications of further steps on the road to EU. As Nugent (1992: 325) has noted, in the future, greater attention would have to be given to applying the principle of subsidiarity and also making EC decision-making more democratic and transparent. Indeed, over the last years, these three issues have converged into a genuine constitutional debate.

The EC's relaunch in the late 1980 s bore semblance to the early 1970 s during which the EC strategy was to simultaneously pursue completion, deepening and widening. Likewise, a parallel could be drawn between the first EC enlargement and the latest one. The EFTA states' main motives for applying to join the EC showed a remarkable similarity with those of the UK, Denmark and Ireland: attention focused around the economic benefits of membership and the perception that it was now politically essential for each country to fully participate within EU decision-making. Another similarity could be found in the anticipated effects of enlargement to the EC. The first enlargement brought in members adhering to a minimalist philosophy of integration and this difference in view created difficulties ever since. As noted, the 1995 enlargement does not present an economic challenge, but it might create difficulties for further Community deepening about institutional reform and foreign policy integration. The fact that the EFTA neutrals eventually accepted the finalite politique of the EU and a federalist agenda implicit in it, does not prejudge the position they will take vis-a-vis future developments in the Union on these issues (Granell, 1995: 132). Nonetheless, some analysts (Pedersen, 1993: 44-5) have observed a gradual rapprochement of the foreign policy positions of the EC members and the EFTA countries during the last few years, which does warrant some optimism as to the possibility of creating an effective CFSP in an enlarged Union. 
The 1995 enlargement has more in common with past enlargements; it is certainly the last "classical" enlargement which has conformed to the traditional integration model and the Community method of enlargement $t^{34}$. The prospects for a EU beyond 20 members raises the possibility of a more radical approach, hence questioning some basic assumptions of the Community method. Furthermore, it has already intensified the strategic debate about the future of European integration. One aspect of the debate was particularly relevant to thinking on the future shape of the EU: the prospects for differentiated integration.

\section{Reconciling Deepening and Widening of the Union: The Search for Differentiated Integration}

Unlike the 1970s and 1980s when flexible arrangements, mainly the notion of a multi-speed Europe were used against recalcitrant states in order to prevent fracturing and drifting apart in an enlarged Community, they have recently been portrayed as something to be inevitable or even desirable (Nugent, 1995: 5). More importantly, a differentiated EU is seen as a means of reconciling the goals of widening and deepening. Unlike the previous examples of enlargement and integration, the current deepening and widening of the Union will not prove easily compatible. In view of the complexity of issues raised by further enlargement, some redefinition of the concept of deepening is inevitable, if widening is to proceed further.

When the Christian Democratic Union and Christian Social Union (CDU/CSU) grouping in the German Bundenstag issued a policy paper entitled "Reflections on European Policy" in September 1994, the debate about differentiated integration was revitalised ${ }^{35}$. What the document became known for is its call for realisation of the models of multi-speed or variable geometry-though not an à la carte Europe-with clear emphasis on a hard core of probably five countries, that is France and Germany as an "inner core" and the Benelux countries ${ }^{36}$. This core, should not only par-

34 See Preston (1996).

35 The full text of the CDU/CSU paper is reproduced in European Access, No. 5, October 1994, pp: 11-5.

36 A multi-speed Europe can be defined as the mode of differentiated integration according to which the pursuit of common objectives is driven by a core group of member states which are both able and willing to pursue some policy areas further, the underlying assumption being that the others will follow later (Stubb, 1996: 287). By signifying common commitment to policies, but differing timing of implementation, or simply "integration differentiated by time", a mulli-speed Europe tries to avoid a possible undermining of the Communily system (Stubb, 1996: 287).

Variable geometry can be defined as the mode of integration differentiated by space which admits to unattainable differences within the integrative structure by allowing permanent or irreversible separation between a hard core and lesser developed integrative units (Stubb, 1996: 287). Accordingly, variable geometry implies a tendency of a number of member states to opl-up by pursuing deeper inlegration outside the acquis communautaire and the Communily decision-making struclure. The basic motive that underlies this model is to "Europeanize" some policy areas in which "communitarization" is either premature or perhaps inappropriale. 
ticipate in all Union policies but also act more Union-oriented than others, and should be the motor of initiatives especially in the new Maastricht policies.

Although the German paper suggests that "this core must not be closed to other member states; rather, it must be open to every member state willing and able to meet its requirements", it was severely criticized by some EU members (Spain, Italy and the UK) for at least two reasons: First, it was perceived as advocating not so much a multi-speed Europe as a two-speed Europ, second, it identified which member states would likely to be in the inner and outer circles (Nugent, 1995: 6-7).

Alternatively, John Major's vision of Europe was of a Europe à la carte, whereby member states are able to pick and choose as from a menu in which policy area they would like to participate, while at the same time holding only to a minimum common objective (Stubb, 1996: 288) ${ }^{37}$. The single-market related policies would be the common policy core for all member states, with future development based on intergovernmental rather than Community institutions (Federal Trust, 1995: 33) (38 $^{36}$ So far, this extremely flexible option of a "Europe à la carte" or "pick and choose Europe" have been rejected by most other member governments.

In the second half of 1995, the central forum of the reform debate on EU was the Reflection Group which was formally set up in early June 1995. However, as Hennes (1996) has marked the preparatory consultations of the group showed how narrow the scope for reforms has been in the EU. In addition to the traditional minimalist states, Sweden and Finland feared further losses of their national sovereignty. Yet, their opposition was not so open, since "they repeatedly hide behind London's blocking strategy" (Hennes, 1996: 37). Moreover, the smaller member states refused a series of institutional reforms which have been put on the Community agenda in recent years, since these would amount to weakening their position. Indeed, political uncertainty is one of the difficulties confronting the EU at the moment. If political leadership-both supranational and national-deems necessary for further deepening of integration, as has been experienced in the 1985 reform process, one has to ask whether such leadership will be forthcoming.

The Reflection Group published its final report in December 1995 which outlines a clear vision for flexible integration ${ }^{3}$. Rejecting à la carte integration, the report

37 John Major made his vision of Europe explicil in his Leiden speech in September 1994. The full lecture is reproduced in European Access, No. 5, October 1994, pp: 6-10.

38 As Stubb (1996: 289) has marked, the main distinction between variable geometry and Europe à la carte is that the former exemplifies a certain opt-in or opt-up to a conglomeration of member states which have already pursued deeper integration in a specific policy area (e.g. the Schengen agreements) The latter, on the other hand, is a form of differentiation in which a member state opts-out or opts-down away from a specific policy area (e.g. the UK and the Social Chapter).

39 See The Reflection Group Report (1995). 
considers multi-speed integration to be applicable as long as it is temporary and as long as the acquis and the single institutional framework is to be respected (Stubb, 1996: 293). The Group also points out that the degree of differentiation could vary according to the pillar and also between the present member states and the current and potential candidates. While certain Community matters such as the internal market and the Community law associated with it, will not function with differentiation, the two intergovernmental pillars may not function without a greater degree of flexibility. Regarding the acceding countries, while some of them will need transitional arrangements for the full acceptance of the acquis, they are not likely to be accorded permanent derogations as such Britain and Denmark have recently obtained. Any long-term differentiation between the new members and the original Union would be unacceptable.

The strategic debate about the future development of the EU has a particular relevance for the rest of Europe. It may be argued that, a Union constructed according to variable integration model would also be open towards differentiated models of cooperation with European third countries, allowing them the status of partial membership-either individually or collectively. Two recent examples of partial membership of the EU is the EEA agreement and the "structured partnership" with the CCEE which was formally launched at the Essen Summit (December 1994) ${ }^{40}$. While partial membership could be seen as a transitional strategy by providing alternatives to either full membership or non-membership, the EEA experience suggests that too much constructing of the boundaries between insiders and outsiders could be unsatisfactory for both sides.

It has been further argued that (Pedersen, 1993: 43) if Europe moves in the direction of variable integration and cooperation, widening will cease to be a major problem for the CFSP. Keeping economic integration distinct from foreign policy integration might allow scope for the non-EU countries to be engaged in some, but not all pillars of the Union. Turkey, Norway and some CCEE might be more easily associated with the CFSP, including the emerging common European defence structure. Indeed, at the June 1992 Bonn meeting, the nine WEU ministers invited other European members of NATO to become associate members of the WEU "in a way which would give them a possibility of participating fully in the activities of the WEU" (Petersberg Declaration, 1992, Section III, Paras A-B). This offer led Iceland, Norway and Turkey to assume associate member status of the WEU in May 1994. In view of

Under this model of arrangement, a state is allowed to participate in some, but not all of the Union's variable integration areas, though without being granted full membership nights in the areas in which it takes part. A more advanced from of partial membership is the model of "affiliate membership" launched in 1991 by the Vice-President Frans Andriessen. It would provide full membership rights and obligations in some areas, while excluding others, at least for a transitional period. 
the fact that Turkey's chances of securing full EU and WEU membership are slight, but, nonetheless, the geopolitical importance of the country for Europe's security still continues, it has been suggested that (Duke, 1996: 184) Turkey's association with the WEU should be clarified during or soon after the IGC.

The prospects for a wider Europe is, then, not a move towards an à la carte Europe which would be a radical departure from the basic principles of equality and solidarity of the EU, but to experience temporarily the model of variable geometry, taking the form of different speeds towards full participation in all fields, rather than permanently different tiers. Clearly, a transitory model involving a "hard core" of states seems more appropriate to attract all members at a later point in time, so that full coherence within the Union could be re-established.

Even though the EU countries might have to accept the inevitability of a flexible Union, differentiated integration has its drawbacks, however. There is a consensual view that all models of differentiated integration should respect both the acquis communautaire and the single institutional framework. While the options of multi-speed and à la carte work within a single institutional framework and maintain the established acquis communautaire, variable geometry takes place outside the acquis and has a tendency to push for deeper integration outside the Community structure. In other words, variable geometry signifies integration via policy deepening but nonetheless, brings about an element of uncertainty over the future of Community decision-making. On the other hand, the models of multi-speed and à la carte raise the question of how and to what extent the states in the outer core would participate in the single institutional framework. In brief, a single institutional framework should exist, yet its functioning would have to be adapted in soma policy areas where not all members participate.

The foregoing discussion suggests that the EU must not only develop sufficient flexibility to spread the advantages of membership to the countries further East. It must also enhance the effectiveness and democratic accountability of its institutions. Thus, one of the crucial issues regarding the future development of the EU is the question of balancing commonality and diversity as well as effectiveness and democracy (Hughes, 1996: 8). Not surprisingly, the current IGC is intended to assess the functioning of the TEU and to consider the institutional questions surrounding enlargement, as set out in the conclusions of the Corfu Summit. Yet, the institutional changes required are of such magnitude that a successful outcome to the IGC is doubtful ${ }^{41}$. In addition to the traditional split between the majority and minority group, bargaining on institutional issues may be seen as a trade-off between the larger and smaller countries. In the past, the latter have been among the most enthusiastic sup- 
porters of the shift to a more federalist EC, largely because it gave them greater weight than their size allowed. The agreement to revise the weighting of votes at the Conference so as to prevent any decline of the voting power of the larger states in the Council would hardly win an easy acceptance of the smaller states. Clearly, the conditions for compromise are problematic because of the need to find consensus as many as fifteen member states now. Even making European integration more flexible does, in fact, not enhance the prospects for profound institutional reform, as again compromises with the more reluctant members states have to be found.

Furthermore, since many of the issues concerning enlargement (EMU, the revision of the CAP, the EU budget and structural funds) will be dealt with after the IGC, it seems likely that the Conference may focus on improving the functioning of the EU-15, rather than directly addressing the needs of a much wider and more diverse Union, including the issue of differentiated integration (Hughes, 1996: 8). In fact, to compensate for the meager outcome of the IGC, the member governments may even present enlargement as a sign of the Union's vitality.

\section{Conclusion}

The debate on widening and deepening has been a recurrent theme on the Community's agenda since its creation. Central to the relationship between widening and deepening is the question of whether or not the two objectives can proceed in parallel, or, whether widening will contribute or retard the Community process of deepening. It is the theme of this article that widening has so far been accompanied by modest deepening via limited institutional reform which resulted in the eventual extension of the powers of the EC's institutions. However, during most of the stagnant 1970 s and early 1980s, which saw the accession of three northern members and one southern member into the EC, there has been a perceived gap between the processes of widening and deepening. While the frontiers of the EC were extended northward and southward, the pace of Community deepening was slow and uneven (between policy and institutional deepening).

The Community's first enlargement in 1973 contributed to policy deepening, albeit on a selective basis. Yet, the 1973 and 1981 enlargements brought in new members that challenged the orthodox thinking about the future direction of European integration and were more disposed to intergovernmentalism. The UK, Denmark and Greece comprised a minimalist group, though not large enough to undermine the overall consensus within the EC for further integration, but nonetheless sufficiently large to circumscribe the nature and scope of institutional and policy reforms of the Community.

The prospect of Iberian enlargement, coupled with the crisis of declining competitiveness and paralysis of the EC legislative process, led to the SEA, signed in 
February 1986. Expanding both the policy scope and institutional capacity of the Community, the SEA resulted in a significant deepening of political and economic integration. Likewise, the two IGCs were, in a sense, a response to the unfinished business from the past-with the move from internal market to EMU, with further reform of the Community institutions and policies, with the move from EPC to CFSP-as well as to the crisis of German reunification.

Although the relationship between deepening and widening has preoccupied the negotiations for the Maastricht Treaty, most of the member states expressed a preference for continuing deepening before the next round of enlargement. One consequence of this tendency was the fact that the Maastricht Treaty, unlike its predecessor, failed to establish the institutional blueprint for the next enlargement of the Union. This did not, however, deter the EU from admitting the three EFTA states, provided that they would be able to adopt the acquis and willing to accept the goal of an increasingly integrated Community.

Arguably, the 1995 enlargement is a partial response to the Maastricht ratification crisis, compounded by continuing economic recession and the EU's failure or poor performance in the former Yugoslavia. One aspect of the political crisis which the Union has experienced in the post-Maastricht period was of particular significance for the EU's future; growing popular concern about the implications of further deepening of integration, as integration process impinges more and more on sensitive issues of national sovereignty. Thus, in contrast to previous decades when there was a "permissive consensus" on European integration, public support can no longer be taken for granted ${ }^{42}$. The erosion of the consensus has obliged member states to tackle the problem of democratic deficit both in the narrow sense of political accountability and in the broad sense of concern for the legitimacy of the Union.

The previous enlargements, far from redressing the democratic deficit, have accentuated it further. Of the northern entrants, the British and Danes, sometimes added by the Greeks, had long resisted to the proposal for direct elections and increased political accountability at the EC level. The Iberian members, notably Spain, have comparatively been more inclined toward the EC's federal development. The poorer southern members have fought for the reform of the EC regional policy and the structural funds, concomitant to deepening of market integration. Yet, in the Spanish view, economic and social cohesion was linked to progress toward political union, and did not pose a threat to the Community method and interests. Furthermore, the particular insistence of the Spanish on introducing a chapter on European citizenship into the TEU may be seen as an attempt to reinforce EC's democratic legitimacy. 
Both the EFTA enlargement and the probable Eastern enlargement will consideraby add to the continuing democracy and legitimacy challenge of the EC. Since the EFTA states have had the tradition of participatory democracy and particularly the use of referanda, it seems likely that these states will press for further democratic controls by the national parliaments, for more transparency in EU decision-making, and they will be strong advocates of the application of subsidiarity. The ongoing process of democratization in Central and Eastern Europe also makes strengthening the EU's own democratic processes more important. Thus, further efforts to redress the democracy deficit will have to be made in order to meet the expectations of the EC's own population as well as those of the CCEE.

As the pressures for widening has grown, not only the legitimacy of the EC model of integration but its flexibility and adaptability are also in question. In its present state, the EU is incapable of facing up the three major challenges, namely, assuring an efficient and democratic system of governance, extending EU membership to the CCEE and regaining the support of its citizens. Although, at first glance, these goals seem difficult to reconcile, in fact, they are closely related: a EU that does not strengthen its institutions before enlargement will degenerate into a wider free-trade area, and a weak Union will provide neither stability to Eastern Europe nor cohesion to Western Europe.

The strategy of differentiated integration seems to be the only viable solution to the dilution that further enlargement will bring to the Union. Such a pragmatic approach to enlargement should give the Community time to deepen itself sufficiently with necessary reforms by the time of entry of the CCEE. It should also allow the aspirant countries to progress to full membership gradually. In a differentiated EU, the associate members could be drawn into EC's institutional, political and legal system by granting them partial membership until conditions are met for full membership on both sides.

Nevertheless, it seems likely that most bargaining on enlargement will take place among the existing EU members, rather than between them and the candidate countries. As the experience of previous enlargements suggest, agreement on another comprehensive reform package will be harder to attain in a EU of 15, especially when the poorer members are keen on strengthening their position against the competing demands of the applicant countries.

The prospect of enlargement may give an impetus to further deepening. However, the deepening process seems more likely to achieve if favourable external circumstances exist, and if it takes the form of a modest and partial reform package, rather than a qualitative leap, as has been in the case of the SEA. Even then, it still requires political leadership-at both national and supranational levels-to persuade governments and peoples to accept the changes and reforms needed. 


\section{REFERENCES}

Bideleux, R. (1996), "The Southem Enlargement of the EC", in R. Bideleux and R. Taylor (eds), European Integration and Disintegration, London: Routledge, 127-153.

Bieber, R. et al (1985), An Ever Closer Union? A Critical Analysis of the Dralt Treaty Establishing the European Union, Brussels: Commission of the EC/The European Perspectives Series.

(1988), 1992 One European Market? A Critical Analysis of the Commission's Internal Market Strategy, Baden-Baden: Nomos.

Cameron, D. (1992), "The 1992 Initiative: Causes and Consequences", in A. Sbragia (ed.), Euro-Politics: Institutions and Policy-Making in the New European Community, Washington: Brookings Institution, 23-74.

Cameron, F. (1995), "The European Union and the Fourth Enlargement", Joumal of Common Market Studies, 33, Annual Review, 17-34.

Commission of the EC. (1985), Completing the Intemal Market. White Paper from the Commission to the European Council, Brussels: COM (85) 310.

(1986), Single European Act, Bulletin of the EC, Supplement 2-86.

ment 3-92.

(1992) "Europe and the Challenge of Enlargement", Bulletin of the EC, Supple-

Corbett, R. (1993), Maastricht, From Conception to Ratification: A Comprehensive Reference Guide, Essex: Longman.

Corbey, D. (1995), "Dialectical Functionalism: Stagnation as a Booster of European Integration", Intemational Organization, 49 (2), 253-84.

Den Hartog, A. (1992), "Greece and the European Political Union", in F. Laursen and S. Vanhoonacker (eds.), The Intergovemmental Conference on European Political Union, Maastricht: European Institute of Public Administration, 80-97.

Duff, A. et al (eds.) (1994), Maastricht and Beyond: Building the European Union, London: Routledge.

Duke S. (1996), "The Second Death (or the Second Coming?) of the WEU", Joumal of Common Market Studies, 34 (2), 167-96. 
Edwards, G. (1991), "The EC and EFTA: Wider but Deeper?", Paradigms, 5 (1-2), 28-41.

European Council of the EC. (1992), Conclusions of the Presidency in Lisbon, 26-27 June 1992, Agence Europe, 28 June 1992.

(1993), Conclusions of the Presideny in Copenhagen, 21-22 June 1993, Europe Documents, 24 June 1993.

Falkner, G. and Nentwich, M. (1995), European Union: Democratic Perspectives After 1996, Wien: Service Fachverlag.

Federal Trust. (1995), Building the Union: Reform of the Institutions, Federal Trust Papers No. 3, London: PSI Publishers.

George, S. (1990), An Awkward Partner. Britian in the European Community, Oxford University Press.

George, S. (1992), "The EC in the New Europe", in C. Crouch and D. Marquand (eds), Towards Greater Europe? A Continent Without An Iron Curtain, Oxford: Blackwell Publishers, $52-63$.

Granell, F. (1995), "The EU's Enlargement Negotiations with Austria, Finland, Norway and Sweden", Joumal of Common Market Studies, 33 (1), 117-41.

Hartley, T. (1993), "Constitutional and Institutional Aspects of the Maastricht Agreement", International and Comparative Law Quarterly, 42 (2), 213-37.

Hennes, M. (1996), "The Reflection Group of the European Union", Aussen-Politik, 1/96, 3340.

Holland, M. (1993), European Community Integration, London: Pinter.

Hughes, K. (1996), "The 1996 Intergovernmental Conference and EU Enlargement", International Affairs, 72 (1), $1-8$.

Kahraman, S. (1996) Institutional Reform and Political Change in the European Community: From the 1950 s to the 1980s, Unpublished Ph. D. diss., Ankara: Middle East Technical University.

Keohane, R.O. and Hoffmann, S. (1991), "nstitutional Change in Europe in the 1980s", in R.O. Keohane and S. Hoffmann (eds), The New European Community: Decision-Making and Institutional Change, Boulder, Co.: Westiew Press, 1-39.

Langeheine, B. and Weinstock, U. (1985), "Graduated Integration: A Modest Path Towards Progres", Joumal of Common Market Studies, 23 (3), 185-97. 
Laurent, P.H. (1994), "Widening Europe: The Dilemmas of Community", The Annals of the American Academy of Political and Social Science, 531, 114-40.

Laursen, F. and Vanhoonacker, S. (eds.) (1992), The Intergovemmental Conference on European Political Union, Maastricht: European Institute of Public Administration.

Laursen, F. (1993), "The Maastricht Treaty and Its Implications for the Nordic Countries", Cooperation and Conflict, 28 (2), 115-41.

. (1994), "Denmark and The Ratification of the Maastricht Treaty", in F. Laursen and S. Vanhoonacker (eds.), The Ratification of the Maastricht Treaty: Issues, Debates and Future Implications, Dordrecht: Martinus Nijhoff Publishers, 86-102.

Lindberg, L. and Scheingold, S. (1970), Europe's Would-Be Polity, New York: Prentice Hall.

Lodge, J. (ed.) (1986), European Union: The European Economic Community in the Search of a Future, London: Macmillan.

(1987), "The Single European Act and the New Legislative Cooperation Procedure", Joumal of European Integration, 11 (1), 5-28.

(1989), "The European Parliament, From Assembly to Co-legislature: Changing the Institutional Dynamics", in J. Lodge (ed), The European Community and the Challenge of the Future, London: Pinter, 58-79.

(1990), "EC Decision-Making: Towards the Single European Market", in D.W. Urwin and W.E. Paterson (eds.), Politics in Westem Europe Today, London: Longman, 20626.

Ludlow, P. (1991), "The European Commission", in R.O. Keohane and S. Hoffmann (eds), The New European Community: Decision-Making and Institutional Change, Boulder, Co.: Westview Press, 85-132.

Michalski, M. and Wallace, H. (1992), The European Community: The Challenge of Enlargement, London: RllA.

Miles, L., et al (1993), "Integration Theory and the Enlargement of the European Union", in C. Rhodes and S. Mazey (eds), The State of the European Union, Vol. 3, Building a European Polity?, Boulder, Co.: Lynne Rienner, 177-94.

Moravcsik, A. (1991), "Negotiating the Single European Act", in R.O. Keohane and S. Hoffmann (eds), The New European Community: Decisionmaking and Institutional Change, Boulder, Co.: Westwiew Press, 41-84. 
Moravcsik; A. (1994), "Preference and Power in the European Community: A Liberal Intergovernmentalist Approach", in S. Bulmer and A. Scott (eds), Economic and Political Integration in Europe: Internal Dynamics and Global Context, Oxford: Basil Blackwell, 29-80.

Nugent, N. (1992), "The Deepening and Widening of the European Community: Recent Evolution, Maastricht and Beyond", Joumal of Common Market Studies, 30 (3), 311-28.

Nugent, N. (1995), "Editorial: Redefining Europe", Joumal of Common Market Studies, 33, Annual Review, 1-16.

Pedersen, T. (1992), "Political Change in the EC: The Single European Act as a Case of System Transiomation", Cooperation and Conflict, 27 (1), 7-44.

(1993), "The Common Foreign and Security Policy and the Challenge of Enlargement", in $\mathrm{O}$. Norgaard et al (eds), The European Community in World Politics, London: Pinter, 31-51.

(1994), The European Union and the EFTA Countries, London: Pinter.

Pinder, J. (1991), The European Cornmunity: Building a European Union, Oxford: Oxford University Press.

Preston, C. (1995), "Obstacles to EU Enlargement: The Classical Community Method and the Prospects for a Wider Europe", Joumal of Common Market Studies, 33 (3), 450-63.

Redmond, J. (ed.) (1992), The Extemal Relations of The European Community: The International Response to 1992, London: Macmillan.

Redmond, J. (1993), The Next Mediterranean Enlargement of the EC: Turkey, Malla and Cyprus, Aldershot: Dartmouth.

Rosenthal, G. (1982), The Mediterranean Basin: Its Political Economy and Changing International Relations, London: Butterworths.

Rummel, R. (1994), "West European Cooperation in Foreign and Security Policy", Annals of the American Academy of Political and Social Science, 531, 112-23.

Siotis, J. (1983), "Greece: Characteristics and Motives for Entry", in J.A. Payno and J.L. Sampredo (eds), The Enlargement of the European Community, London: Macmillan, 50-72.

Stubb. C-G, A. (1996), "A Categorization of Differentiated Integration", Joumal of Common Market Studies, 34 (2), 283-95.

Taylor, P. (1983), The Limits of European Integration, London: Croom Helm. 
.--...---.---.. (1989), "The New Dynamics of EC Integration in the 1980s", in J. Lodge (ed), The European Community and the Challenge of the Future, London: Pinter, 3-25.

"The Community's Enlargement: The Benelux Memorandum", submitted to the European Council of Lisbon, Europe Documents, 27 June 1992, No. 1789.

The Reflection Group Report (1995), SN 520/95 (REFLEX 21), Brussels, 5 December.

Tindemans, L. (1976), Report on European Union, Bulletin of the EC, Supplement 1-76.

Tranholm-Mikkelsen, J. (1991), "Neofunctionalism: Obstinate or Obsolete?", Millennium: Journal of Intemational Studies, 20 (1), 1-22.

Tsoukalis, L. (1981), The European Community and Its Mediterranean Enlargement, London: George Allen and Unwin.

Van K. Kersbergen and Verbeek, B. (1994), "The Politics of Subsidiarity in the European Union", Joumal of Common Market Studies, 32 (2), 215-36.

Vemey, S. (1987), "Greece and the EC", in K. Featherstone and D. Kautsoudas (eds), Political Change in Greece: Before and After the Colonels, London: Croom Helm, 253-70.

Wallace, H (1985), Europe: The Challenge of Diversity, London: Routledge and Kegan Paul for the RIIA.

Wallace, H. (1989), Widening and Deepening: The European Community and the New European Agenda, London: RllA.

Wallace, W. (1983), "Less Than a Federation, More Than a Regime: The Community as a Political System", in H. Wallace et al (eds), Policy-Making in the European Community, Chichester: Wiley.

Wilke, M. and Wallace, H. (1990), Subsidiarity: Approaches to Power-Sharing in the European Community, London: RIIA. 